Scientific Journal Warsaw University of Life Sciences - SGGW

Problems of World Agriculture volume 19 (XXXIV), number 3, 2019: 23-34

DOI: 10.22630/PRS.2019.19.3.43

Yuriy Hubeni ${ }^{1}$, Volodymyr Krupa ${ }^{2}$

Lviv National Agrarian University, Ukraine

\title{
Land Transformations in Ukraine: Problems and Expectations
}

\begin{abstract}
The analysis of urgent problems of land relations transformation and of forming agricultural land market in Ukraine is carried out in the article. The general characteristic of main reform stages is given. The reasons of lasting action of the moratorium on agricultural land sale-purchase being the chief obstacle for complete market development are defined. Supporters' and opponents' arguments about moratorium canceling, population estimation of advantages and threats of land circulation are described. The results of the research project "Farmers' land expectation" made by the authors are given. The project purpose was studying population rational expectations concerning the directions of further land reform development and its results. The research was conducted on the local level in rural surrounding, which is characterized by high competition level among agrarian business subjects at agricultural land lease market. Landowners' and other interested group people' opinions concerning lease cost, potential sale price, inclination towards land sale, possibilities of farmers' common farming on their own land, leaseholders' participation in social and economic development of rural areas are examined. High level of farmers' uncertainty about land market indicators because of knowledge lack and low level of land reform information support is established.
\end{abstract}

Key words: land reform, land relations, agricultural land market, moratorium, land lease

JEL Classification: Q15, R52

\section{Introduction}

Land reform is one of the most complicated and continuous reform realized in Ukraine today. Its start right after obtaining independence was caused not only by the desire of the government to create strong economic and motivational basis for agrarian entrepreneurship development. It was also the reaction to the key needs of the Ukrainian society, the significant part of which connected its economic interests and well-being with the work on land. At last Ukrainian peasants got the chance of land ownership and of becoming real farmers.

However, the process of land relations reforming at its first stage (years 1991-2000) turned out to be too hasty. Distinct reform programme, appropriate legislative base were not elaborated, the informational accompaniment of denationalization and land privatization was not sufficient. Peasants were not explained about the opportunities to organize common farming, but on new market principles. As a result, transformation processes in land sphere were realized extremely irregularly in the regions. In western regions they were rather active, but in the central and eastern regions land relations development has been conserved for a long time and collective farming model was preserved there.

Nevertheless, the achievements of this reforming stage became as follows: recognition of land private ownership institutions, sharing lands and turning them over to the peasants'

\footnotetext{
${ }^{1}$ Dr. Scs., professor, Lviv National Agrarian University, V. Velykyi str, 1, Dubliany, Zhovkva district, Lviv region, 80381, Ukraine, e-mail: hubeni@ukr.net; https://orcid.org/0000-0002-1842-8975

${ }^{2} \mathrm{PhD}$, associate professor, Lviv National Agrarian University, e-mail: v_krupa@ukr.net; https://orcid.org/0000-0001-8658-7735
} 
property, issuing appropriate legal documents to landowners. It ensured the conditions for development of farms and other market type agrarian formations.

A new stage of land reform was marked by adopting Land Code of Ukraine in 2001. This legislative act opened wide opportunities to form land relations in harmony with the developed world on the conditions of possessing, using and disposing of land resources, which would ensure peasants' full land ownership, understandable for national and foreign partners (Hadzalo, Luzan, 2017). At this stage the normative monetary land evaluation was introduced, state land cadastre was created, a number of problems concerning land lease relations. On the whole, preconditions for forming a new segment of market relations, that is agricultural land market (Stupen, 2018). However, because of some economic and institutional problems this market has not fully worked so far. The main reason consists in prolongation of moratorium on agricultural land sale and purchase till 2020. This problem remains the acutest social and political contradiction of Ukrainian society. But behind it still pressing problems of agrarian sphere functioning are hidden, forming considerable threats for land reform goals realization and distorting the present land relations mechanism.

Large-scale investments of private companies in agrarian sector enabled to involve a great quantity of lands in economic turn-over. But oligopolization and "oligarchization" of the branch caused additional contradictions between the subjects of land relations and confirmed skeptics' doubts concerning transparency of land market formation.

Poverty, social and every day problems, difficulties of independent farming, lack of efficient state support made farmers lease their lands to large agroindustrial companies. But their activity does not meet the principles of stable development, as economic interests dominate ecological and social interests of farmers. Agroholdings practice intensive monocultural type of production, causing soil exhaustion, its chemical pollution and fertility decrease. The lack of efficient mechanisms of state and public controlling land use and protection does not enable rural people to protect their interests and violated rights in the sphere of land tenure. It causes considerable public response and disappointment with the land reform success.

Taking unsatisfactory situation of land relations development, threats to resource, food and social components of economic security of the country into consideration, it is very important to avoid new mistakes and simplified approach to fulfilling the modern land reform stage. The search for optimal decisions in this sphere requires improving the research of the existing problems, analyzing hidden risks of political resolutions and legislative initiatives, but what is more important - it's examining landowners' expectations - those people who will make final decisions concerning disposing of land under conditions of unstable economic and social situation in the country.

In view of the above the purpose of our research is market preconditions, problems and social mood estimation on the eve of realizing the final stage of land reform in Ukraine - that is, introducing free circulation of agricultural lands.

In the process of research the following tasks were set:

- to characterize the present model of agricultural land market, which was formed as a result of land reform realization;

- to estimate the problem of moratorium on agricultural land purchase - sale;

- to investigate the expectations of land share holders of introducing free circulation of agricultural land, the degree of its differentiation and risks connected with them. 


\section{Materials and Methods}

In the process of the research the following methods were used: abstract and logical (for elucidating land relation as nature and the character of correlation between land transformation processes), historical (for studying main land reform development stages, understanding the reasons for present-day state in this sphere), statistical (analysis of land market development indices, its structure, comparison of land lease and land sale prices in Ukraine and European countries, generalizing research results).

The data of State service of Ukraine for Geodesy, Cartography and Cadastre (StateGeoCadastre); materials of social surveys conducted with the promotion of USAID; data of Eurostat; materials of the research project made by the chair of entrepreneurship, trade and exchange activity of Lviv National Agrarian University were the sources of information.

Within the framework of the mentioned project, using the methods of statistic observations, the research of land relations on the local level was conducted. Certain villages of Busk district, Lviv region, were chosen research object. The object choice was made after consultations with experts and representatives of administration bodies, as well as on the grounds of estimating some territorial and demographic parameters. High level of leaseholders' competition for farmers' land shares played an important role in the choice. Seven enterprises here compete for the right of land lease. Among them there are both large agroholdings and farms. The additional variants of observations were analogical surveys among experts in the sphere of land relations. The interview method was used as an auxiliary observation method in this case. The Internet-users interested in land reform problems were one more target group of the respondents.

\section{Results}

One of main goals and probably the biggest problem of land reform in Ukraine is forming transparent civilized agricultural land market. It is an integral component of agrarian economy and social-economical development of rural territories. While functioning appropriately, this market ensures efficient distribution and usage of arable land, competitive and balanced agriculture development, being an instrument of coordinating the interests of landowners and agribusiness subjects.

Forming agricultural land market is a long-term process, requiring creation of necessary normative and legal base, market infrastructure, organizational and informational maintenance. The mechanism of state regulation and control of keeping legislature in the sphere of land circulation is also necessary. In spite of these problems importance an few real steps are made in Ukraine for their solution and introduction of complete land market. Instead, main attention is focused on land sale and purchase, moratorium abolition, in particular, as it forbids its free circulation.

Some researchers of judicial aspects of this problem think that moratorium on agricultural land sale contradicts art. 14, 22 and 42 of the Constitution of Ukraine, emasculates the essence of land ownership, depriving the owner not only of legitimateness to manage his property, but to receive normal economic effect of his land plot or land share (Litoshenko, 2014).

At the same time, other authoritative scientists claim that the Institute of Private Land Ownership requires improving, but besides ensuring social justice of access to such a 
resource as land, it must promote emerging efficient, in terms of economics and on long term basis, land owners, with their observing the corresponding ecological norms and requirements (Budzyak, Budzyak, 2017). Along with this, they emphasize that practically in all developed countries of Europe and of the world while introducing land market, a number of restrictions have been applied, and afterwards the system of state regulation of agricultural land market circulation was established.

According to VoxUkraine independent analytical platform, approximately $41 \mathrm{mln}$ hectares of land are under the moratorium nowadays, which makes up $96 \%$ of all agricultural land in Ukraine (Fig. 1). It includes 27,7 mln hectares (68\%) - land shares in private ownership; $10,5 \mathrm{mln}$ hectares $(25 \%)$ - agricultural land in state and communal ownership; $1,5 \mathrm{mln}$ hectares (4\%) - land for commodity agricultural production (except shares); $1,3 \%$ mln hectares - non-agricultural land of state and communal ownership. About 6,9 million people or 16,2\% permanent population of Ukraine are land share owners, whom the moratorium concerns. Prevailing majority of them is rural citizens.

The moratorium was put into effect in 2001 for preventing chaos arising in land sphere under conditions when agricultural land market only began to form. Since that time its action has continued every year, which evokes ambiguous assessment among scientists, as well numerous political discussions and manipulations of public opinion.

The opponents' principal arguments against agricultural land sale are:
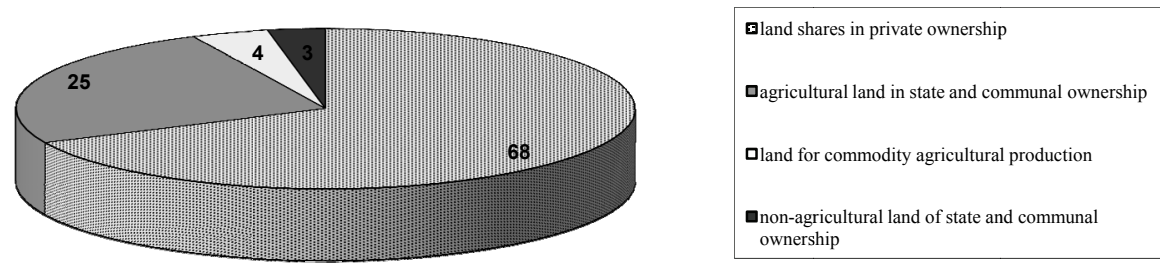

Fig 1. Agricultural land distribution under moratorium on sale and purchase, $\%$.

Source: https://voxukraine.org/uk.

- reform programme is not perfect, it is only aimed at changing owners, it doesn't contain exact mechanism of complex solving the problems of increasing agrarian production efficiency and village social development;

- imperfect legislative base and insufficient corruption combating will promote concentrating land in ownership of oligarchs and foreign companies. It will cause a number of threats to national security, its food component, in particular;

- the effect from land sale for filling the budget and increasing villagers' bell-being will be short-term;

- impoverished rural population will be ready to sell land for a song;

- lack of infrastructure which would ensure proper land market functioning.

The supporters' arguments for free agricultural land circulation are:

- because of the moratorium the farmers can not freely dispose of their land, which violate their constitutional rights and democratic principles;

- a great part of land (more than 1,6 million shares) is in the ownership of people of above 70. These people are not aware of legal aspects of its disposal. Still more than 1 million shareholders died during reform period and did not inherit the land. Such legal uncertainty created preconditions for involving considerable part of land in shadow 
circulation, for illegal land seizure and other abuses. A lot of land is cultivated without concluding agreements as the owner is absent or unable to be identified;

- the moratorium did not ensure developing civilized land relations, promoted agroholdings development and transition to monocultural agriculture, causing soil exhaustion;

- the moratorium prevents attracting investments in agriculture, as because of the lack of "commodity" status land cannot be a subject of a mortgage to take out loans;

- absence of free land market cause understated rent and considerable losses of tax revenues to local budgets by ways of concluding land agreements;

- the moratorium action promotes developing agricultural land shadow market. Nowadays there are several legal ways of changing the right to land ownership, intended for agrarian production or for receiving in long-term use. They include the change of purpose land use, share transfer according to life annuity agreement, land exchange, debt collection, long-term lease (till 50 years).

One of widely spread schemes is emphyteusis - an agreement of the right to use another land plot for agricultural needs, not limited to deadline. As experts claim there are already agreements of emphyteusis, concluded for 100, 200 or 500 years, with one-time payment to the owner for the use of land (Hrab, 2017). In 2016 the right of emphyteusis was registered for 14138 land plots, for the first 6 months of the year 2017 - 10360 plots (Land relations, 2018). Poltava, Odessa and Sumy regions are the leaders of this kind of transactions.

However, the moratorium action restrains the majority of transactions with agricultural lands, that's why lease remains the most spread kind of operations (Fig. 2). Its part makes up $76,11 \%$ of all operations with the given category of land. Moreover, for non-agricultural land lease makes up only $19,32 \%$, sale and purchase $-36,83 \%$.

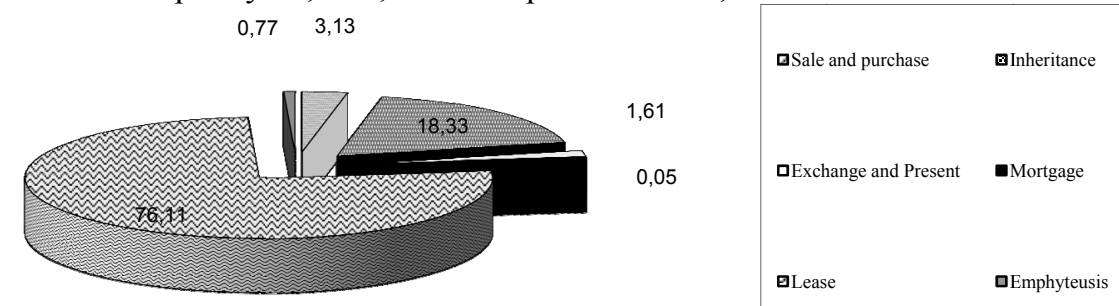

Fig 2. The part of transactions types in total quantity of agricultural land in Ukraine (July 2015 - June 2017)

Source: Land relations monitoring in Ukraine 2016-2017: statistic yearly.

Sale and purchase operations and mortgages concern the land which is not under the moratorium action. They are areas for gardening, vegetable gardening, subsidiary and private peasant farming. They make up 1,7 million ha or $6 \%$ of the total agrarian area.

The problem of the moratorium has considerable political implication. This theme causes political discussions, initiated by the parties - state power opposition. Land questions become a central instrument of pre-election campaign and of voters' opinion manipulation through media resources. It is mass media that are main source of farmers' knowledge about the moratorium, and owing to them land market anti-advertising is performed and farmers' negative expectations of its introduction are nurtured. As a result a distorted notion concerning the further reform strategy is formed in the society.

According to the results of the research "Urgent questions of land reform" conducted in 2017 with the promotion of USAID, almost 2/3 of the citizens declared against cancelling the 
moratorium on selling agricultural land, but almost $\mathrm{S}$ of the respondents were for the opportunity to sell the land they possess if a need arises (Yaremko, 2017). Such a paradox of attitude towards mutually exclusive things is caused by low level of knowledge about the reform and its realization mechanisms. But only $6 \%$ of the respondents get professional unbiased information about land market situation, examine legislation and experts' opinions. That's why there is a wide field for manipulating social opinions by politicians.

Political parties' rhetoric influences citizens' convictions about the advantages and dangers of free land circulation introduction. On the whole $55 \%$ of the Ukrainians think that moratorium cancelling will benefit the country, though $80 \%$ see different dangers in cancelling the moratorium (Fig. 3). The distribution of attitude towards the moratorium in the regions is differentiated depending on the prevailing political sympathies among the population.

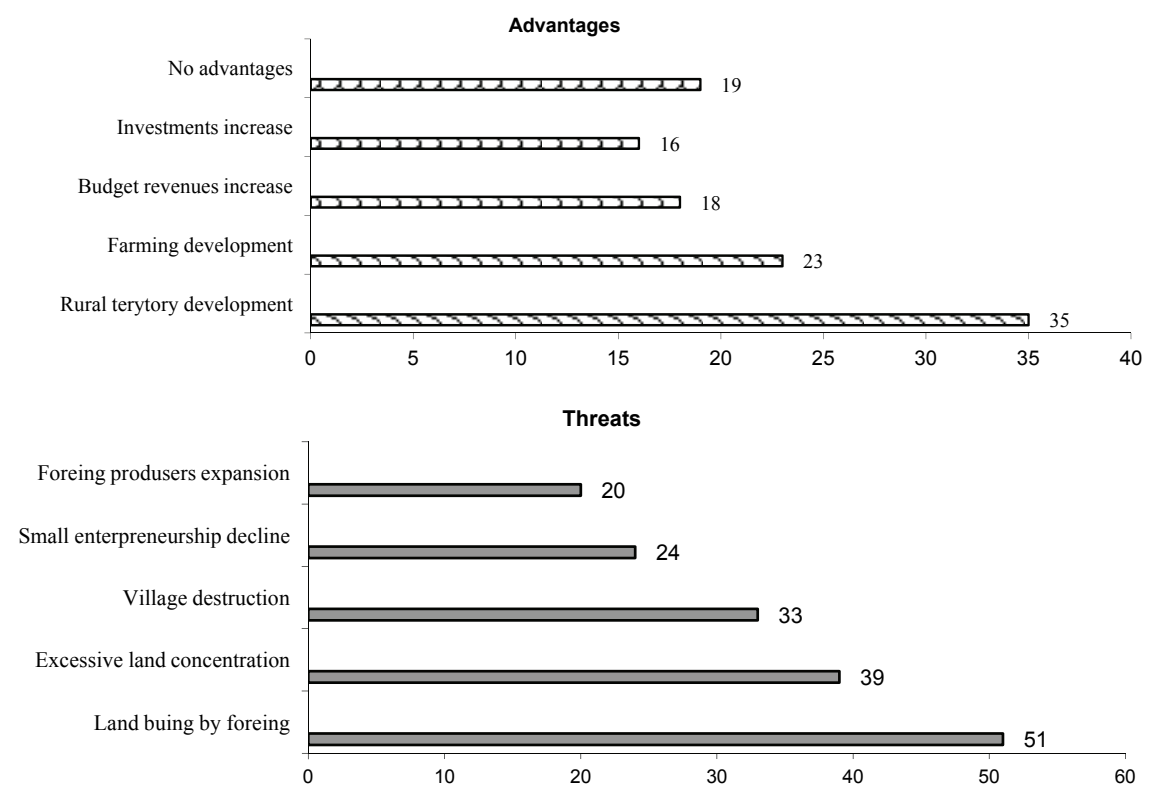

Fig 3. Population evaluation of advantages and threats of land market introduction, $\%$.

Source: drawn up on the basis of (Yaremko, 2017).

One more political component of land market introduction consists in reform blocking by the deputies lobbying the interests of large agribusiness. In scientific and political circles the ideas are expressed that the owners of agroholdings are not interested inland market introduction. Because the rent for 1 ha of arable land, connected with the value of normative monetary land assessment, in different regions fluctuates nowadays between 30 and 100 euro a year (StateGeoCadastre).

Owing to such rent and lack of alternative directions of using land by farmers, large agrocompanies are able to lease hundreds of thousands of hectares. Without control of economical and ecologically safe using this land they can receive maximum high incomes in short-term perspective. To buy the same quantity of land would be impossible because a great amount of capital should be attracted and it would take long time to offset it. Land capitalization is also unprofitable in terms of long-term strategies of company development, 
as the capital invested in land, has low level of liquidity, it will be impossible to quickly withdraw it. One more argument is that land in ownership being a warranty from crushing exploitation induces to take measures of fertility restoration. Degraded and exhausted land has low value, it will be impossible to sell it for production purposes when interests and directions of company activity change.

On the other side, after monopolizing property in land, oligarch groups will be able to transfer it to lease and dictate its conditions in agribusiness and local development.

The results of the research project made by the staff of the chair of entrepreneurship, trade and exchange activity of Lviv National Agrarian University confirm to great extent the above described tendencies and problems of forming land market in Ukraine. The main project purpose was to find out farmers' expectations of land reform under the conditions of substantial competition exacerbation of agroproducers of different property and management forms. The poll was conducted on the basis of such key indicators: expected rent, expected cost of land sale, readiness to sell land or use it independently, participation of leaseholders in village development, landowners' inclination to cooperate for common activity, etc. (Land expectations, 2018).

Target respondents group consisted of shareholders living in rural area. More than a half of them received land after disintegration being workers of agricultural enterprises. Despite the fact that landowners have direct or indirect experience of personal farming, $95,7 \%$ of them transfer shares to lease and don't cultivate on their own. Main reasons of this are: lack of sufficient level of resource maintenance (start capital, buildings, agricultural machines, labour force), lack of special knowledge for conducting competitive agrarian entrepreneurship, age (more than $40 \%$ of the respondents are retired people), social psychological and motivational stimuli of independent farming on their own land not being formed.

Land tenure structure in the region surveyed is rather differentiated: 3 farms, 1 private enterprise and 3 limited companies (of holding type) lease shares. On the whole farms use $55,6 \%$ of shares with the area of $41,4 \%$ of the total leased land area. Such a high level of competition among leaseholders promotes creating transparent and attractive conditions of share lease for landowners. In general, $71 \%$ of respondents are satisfied with lease conditions. However, farmers' desire of rent increase is rather pragmatic. $83 \%$ of respondents want it, while $6,8 \%$ are interested in lease term change, $10,2 \%$ are interested in payment conditions change. Such a situation is expected. Poverty of rural population in Ukraine, insufficiency of income sources on the one hand, and awareness of agrarian business profitability on the other hand objectively form the awareness of necessary increasing farmers' share in income redistribution.

In Ukraine average rent is one of the lowest in Europe and depending on rate fluctuations makes up approximately 41-45 euro a year for a hectare. In comparison, in Estonia it is 52 euro a year for a hectare, in Croatia - 76, in Lithuania - 81, the Czech Republic - 96, Spain - 144, Slovenia - 147, Hungary - 151, France - 201, Great Britain 224, Bulgaria - 225, Austria - 348, Denmark - 536, the Netherland - 791 (Eurostat, 2016).

Landowners' estimates concerning fair rent are rather ambiguous. Only $10,2 \%$ of people agree that it must correspond to the present amount - till 100 euro for a hectare. For $17,3 \%$ of respondents the rent within 100-160 euro for a hectare if acceptable. Still $18,4 \%$ of landowners wish to receive more than 160 euro a year for a hectare. Though, the following fact is interesting, that $54,1 \%$ of shareholders hesitate about their defining acceptable rent for arable land. The people with higher education doubt most of all, as they 
realize that the rent depends on many factors and must correspond to the interests not only of land owner, but of leaseholder as well.

Lease term is also debatable from point of view of realizing the interests of lease relations parties. Land Code of Ukraine defines that maximum term of land lease agreement cannot exceed 50 years. Minimum term of land lease for running commodity agricultural production, farms is defined by parties agreement, but cannot be less than 7 years, and for the land where hydrotechnical land-reclamation was performed - not less than 10 years. These norms wholly correspond to European practice of setting land lease terms (minimum 6-10 years). However, as research results show, 53,8\% of shareholders are not ready to conclude an agreement for the term of above 7 years, and 90,35\% of people are not interested in the term of over 10 years. Not a single respondent considers the possibility of long-term land lease - more than 20 years (Fig. 4).

Such results are entirely objective as payment price conditions, farming traditions and perspective farmers' expectations have changed. It should be mentioned that long-term land lease causes considerable threats to stable agriculture development, limits lease mechanism flexibility, decreases land value and competition at land market. In our opinion, this question can be partly regulated by way of increasing the rent depending on lease term.
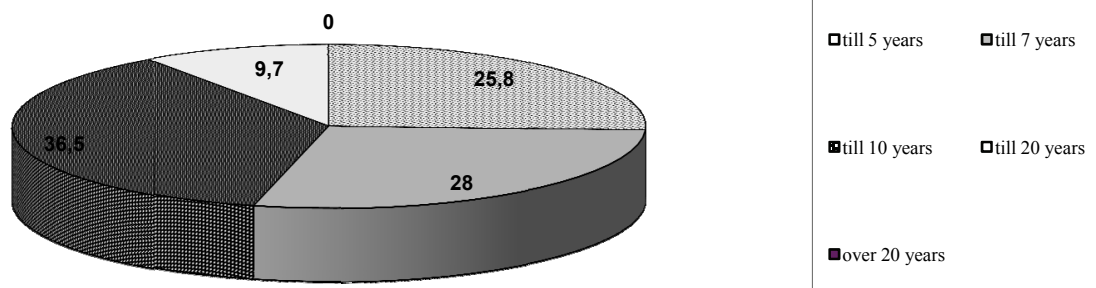

Fig 4. Distribution of respondent opinions concerning terms of agricultural land lease, $\%$

Source: own research.

Expectations and stimuli of the respondents concerning the start of personal farming on the land they possess are not formed. So, 76,8\% of the peasants asked don't see the prospects of independent farming on their own land. Also the expectations of establishing and expanding cooperative movement in the village are pessimistic, because $67,4 \%$ of respondents don't want to integrate and cooperate for common farming. It is mainly caused by high level of individualism among villagers, skeptical attitude towards the opportunity to coordinate the interests of mutually running business and negative associations connected with collective form of farming. It is among old age group people (over 60) that the largest part doesn't want common farming $-77,8 \%$, while in the age group of $41-60$ $51,3 \%$ of people don't want it, in age group till $40-61,9 \%$.

The results of the survey conducted prove that respondents demand to strengthen the responsibility of direct leaseholders on the principles of financing village social and economic infrastructure (43,7\% of respondents), supporting local initiatives $(19,3 \%)$, cooperation with representatives of local authority $(11,8 \%)$, rendering economic assistance to shareholders $(25,2 \%)$. Along with this, $65,6 \%$ of respondents emphasize necessary reports of the producers to the community about the results of farming on the leased land. Such a position is motivated, because landowners can estimate how the results correlate with the rent and the contribution to village development, and accordingly, demand rent 
condition improvement. But 12,5\% of respondents think, that such report is not necessary, as this information id commercial secret, and lease conditions are defined by parties agreement.

Farmers' expectations of free land circulation are of special importance in the context of agrarian reform realization. Our researches conducted on the local level confirm general sentiments concerning this problem in the Ukrainian society. Among target group of respondents only $24,4 \%$ are ready to sell their land share, almost $60 \%$ flatly reject such an opportunity, others - admit it under certain conditions. First of all such conditions are acceptable price or the government's establishing limits concerning sale amount and customer categories. It is characteristic that readiness for land sale distinctly rises depending on age (Fig. 5).

Except for stereotypic notions of threats of buying land by owners of big capital, low inclination to its sale is caused by farmers' uncertainty concerning the future economic situation, employment, incomes. That is, land is considered as a reliable capital, the price of which will not decrease. It is also a warranty of receiving means of subsistence in case of losing other income sources.

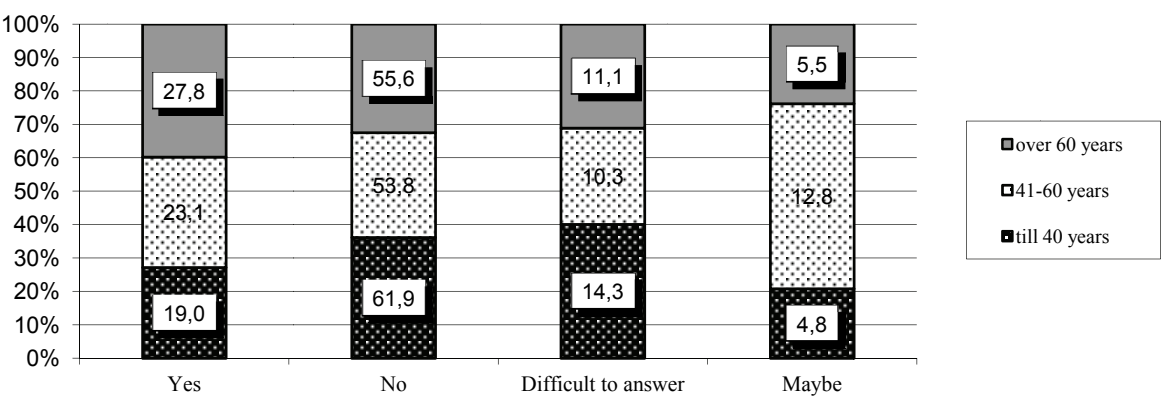

Fig. 5. Inclination of landowners towards land share sale (according to age groups)

Source: own research.

Under the condition of low informational support of land reform, shareholders have rather vague idea of the real land market price (Fig. 6). Almost 30\% of respondents consider objective price of selling it - the sum less 1700 euro (50 000 UAH in equivalent). Such a price approaches normative land price determined by the state, though methods of calculation is imperfect and contradictory.

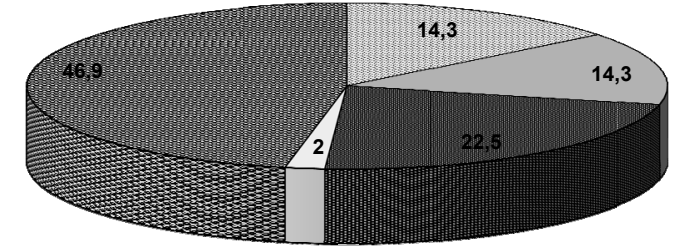

Đless than 1000 euro

田1700-3300 euro

Fig. 6. Estimation of expected market price of 1 hectare of agricultural land by landowners, \%

Source: own research. 
Yet 22,5\% of respondents estimate their own land to cost 1700-3300 euro a hectare. It approaches already the lowest prices in some countries of Europe, particularly in Romania 1958 euro a hectare, Estonia - 2735 euro, Croatia - 2809 euro, Latvia - 2917 euro, Lithuania - 3516 euro (Eurostat, 2016). Though in neighboring Poland, which has similar in quality soil, 1 hectare of arable land costs 9100 euro, and the majority of countries in the western part of Europe it makes up over 10000 euro a hectare. At the same time, 46,95 of land shareholders could not define acceptable for them the price of one hectare of agricultural land. Moreover, the people with higher education - $63,6 \%$ - showed the highest level of uncertainty concerning the price. They try to approach this problem in the most considered and responsible way. And exactly this group of people treats this problem most skeptically, considering that land market price will be (or has to be) too high (Fig. 7).

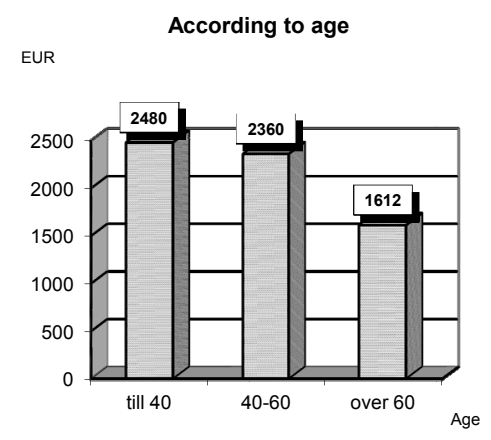

According to education

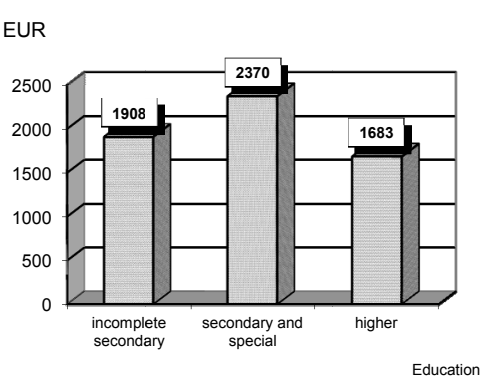

Fig. 7. Average expected price of 1 hectare of agricultural land estimated by different respondent groups

Source: own research.

In age groups pensioners estimate land in a lowest way, because they would like to get rid of it owing to the force of certain circumstances. It proves that balanced approach is necessary for land reform organization and realization step by step, using protective mechanisms against profiteering and abuse in this sphere.

\section{Conclusions}

The research enables to make a number of conclusions concerning dynamics and directions of land reform development, to estimate it in the framework of farmers' expectations.

The first thing to notice is an objective necessity of changes. Nowadays in rural surrounding land tenure was formed, which doesn't promote stable and balanced development of all the components of the country's social and economic system. On the one hand, there is too large quantity of small "landowners", who possess extremely valuable resource, but are unable or do not want to use it efficiently, and at the same time cannot get rid of it. On the other hand, some companies concentrated excessive quantity of leased land, monopolize production sphere and agrarian products market, cause damage to environment, form chiefly export raw structure, don't produce commodity safe for health. As a result public benefit of land as a resource, reduces to minimum. 
The next conclusion is, that a village and rural way of life unceasingly change. It essentially influences land relations, estimation of economic and life prospects by rural population and other landowners. Market relations, material motivation, rational expectations and other factors impel to deepen pragmatism and rationalism. A lot of rural dwellers don't want to adopt traditional rural way of life, they become more mobile and think that property right institution must not be the factor, which "attaches" to the village and agriculture.

The third key thesis is, that land reform realization requires distinctly structured and elaborate programme of actions and strong legislative base. Free land circulation introduction must follow land share stocktaking, creating efficient system of land resources administration, the system of state and public monitoring land usage, elaborating the mechanism of protecting land market from dishonest competition and monopolization, taking measures of agricultural land consolidation. It is reasonable to stimulate advisory activity of state bodies and scientific agrarian centers concerning the rise of farmers' awareness of organizing and bearing land lease relations.

There is urgent necessity to conduct regularly independent "field researches" in rural surrounding. The empiric data received fundamentally supplement other informational materials, and in this way enable to form better base for making decisions on state and local levels. Such information is valuable for subjects of economic activity, as the competition at land relations market becomes more and more acute. That's why big leaseholders have to intensify their corporate social responsibility, improve cooperation with communities, organize the dialogue with owners, take care of protection and land restoration. It is desirable that big enterprises should support local initiatives, not only of social and cultural but also of economic direction.

It is important that land relations mechanism formed as the result of reforms should ensure optimal land concentration, sound competition in the sphere of agribusiness, full satisfaction of economic interests of farmers and subjects of economic activity, and should guarantee state food security.

\section{References}

Agriculture, forestry and fishery statistics - 2018 edition (2018). Publications Office of the European Union Luxembourg.

Budzyak, V., Budzyak, O. (2017). Institutional support of a full-fledged market of agricultural land. Agrosvit, 10, $3-10$.

Dankevych, V., Lukomska, I. (2018). Land market has been launched already. Portrait of Ukrainian model Economic Truth. Retrived May 2019 from: https://www.epravda.com.ua/ publications/2018/11/29/643118.

Eurostat. Retrived June, 2019 from: https://ec.europa.eu/eurostat.

Hadzalo, Ya. M., Luzan, Y.Y. (2017). Land reform: problems and prospects of development of agrarian economy. Economika APK, 1, 5-14.

Hrab, R. (2017). How to ignore the moratorium: 5 most spread schemes. AgroPortal. Retrived June 2019 from: https://agroportal.ua/ua/views/.../kak-oboiti-moratorii-5-samykh-rasprostranennykh-skhem.

Land expectations of farmers: results and analysis of sociological monitoring of land relationships (2018). Ed. Y. Hubeni. Rastr-7. Lviv.

Land relations monitoring in Ukraine: 2016-2017: statistic yearly. (2018). Retrived June 2019 from: http://land.gov.ua/wp-content/uploads/2018/10/monitoring.pdf.

Litoshenko, O. (2014). The problem of the moratorium on sale of agricultural lands. Legal Regulation of the Economy, 14, 284-293.

StateGeoCadastre. Retrived June 2019 from: https://land.gov.ua/ 


\section{Y. Hubeni, V. Krupa}

Stupen, R. (2018). Agricultural land market in Ukraine: development state and perspectives. DKC-Center. Kyiv. Yaremko, V. (2017). Why the Ukrainian is against land market. Economic truth. Retrived May 2019 from: https://www.epravda.com.ua/ publications/2017/07/31/627596.

https://voxukraine.org/uk.

\section{For citation:}

Hubeni Y., Krupa V. (2019). Land Transformations in Ukraine: Problems and Expectations. Problems of World Agriculture, 19(3), 23-34; DOI: 10.22630/PRS.2019.19.3.43 